\title{
Pengaruh Sektor Industri, Sektor Pertanian, Dan Sumber Daya Manusia Terhadap Ketimpangan Pembangunan Di Jawa Barat Tahun 2015-2019
}

\author{
(The Effect Of Industry Sector, Agriculture Sector, And Human Resources On Development \\ Inequality In West Java In 2015-2019)
}

\author{
Ria Nurul Azizah ${ }^{1 *}$, Atik Mar'atis Suhartini² \\ ${ }^{1,2}$ Politeknik Statistika STIS \\ E-mail: 211709974@stis.ac.id dan atik@stis.ac.id
}

\begin{abstract}
ABSTRAK
Jawa Barat merupakan provinsi yang memiliki kontribusi besar terhadap perekonomian Indonesia. Namun, masalah ketimpangan di Jawa Barat menempati urutan ketiga tertinggi di Indonesia dan belum mencapai target pemerintah. Indeks Williamson Jawa Barat selalu berkisar 0,64 setiap tahunnya, yang menunjukkan kategori ketimpangannya tinggi. Jawa Barat merupakan pusat kawasan industri terbesar di Indonesia, tetapi pembangunan industrinya masih belum merata dan terkonsentrasi di kawasan industri. Kondisi ini dapat memperburuk ketimpangan pembangunan antardaerah. Penelitian ini bertujuan menganalisis mengenai ketimpangan pembangunan, perkembangan klasifikasi wilayah, serta pengaruh industri, pertanian, dan SDM terhadap ketimpangan pembangunan di Jawa Barat. Metode yang digunakan, meliputi analisis Tipologi Klassen dan regresi data panel. Hasil penelitian menunjukkan masih terjadi ketimpangan pembangunan antardaerah di Jawa Barat dan terdapat lima kabupaten/kota mengalami perubahan klasifikasi. Jumlah industri, PDRB industri, dan PDRB pertanian berpengaruh positif terhadap Indeks Bonet, sedangkan jumlah tenaga kerja industri, RLS, dan AHH berpengaruh negatif terhadap Indeks Bonet.
\end{abstract}

Kata kunci: ketimpangan pembangunan, industri, Indeks Bonet, regresi data panel

\section{ABSTRACT}

West Java is province having high contribution on Indonesian economy. However, Inequality in West Java are third highest in Indonesia and hasn't reached the government target. Williamson Index of West Java always revolve around 0,64 every year, meaning high category nequality. West Java is the largest of center industrial areas in Indonesia, but industrial development aren't evenly distributed and concentrated in the industrial areas. it can excacerbate development inequality between region. This study aims to analyze the development inequality, regional classification, and the influence of industry, agruculture, and human resources on development inequality in West Java. The methods include Klassen Typology analysis and panel data regression. The results shows large development inequality between region in West Java, changing classification in five region, and number of industri, industrial GRDP, and agriculture GRDP have positive effect on Bonet Index, number of industrial labor, RLS, and AHH have negative effect on Bonet Index.

Keywords: development inequality, industry, Bonet Index, data panel regression

\section{PENDAHULUAN}

Pembangunan ekonomi merupakan interaksi yang berkesinambungan antara sumber daya manusia, sumber daya alam, kapital, dan teknologi, serta terjadinya proses perubahan dan perbaikan secara terencana untuk meningkatkan kesejahteraan hidup masyarakat (Sukirno, 2006). Tujuan pembangunan ekonomi tidak hanya mengejar target peningkatan petumbuhan ekonomi, tetapi harus memperhatikan pemerataan untuk mengurangi ketimpangan pendapatan dan kesenjangan antardaerah (Todaro dan Smith, 2006). Salah satu poin penting tujuan pembangunan berkelanjutan (Sustainable Development Goals/SDGs) di suatu negara, yaitu mengurangi ketimpangan di dalam dan antarnegara. Selain itu, salah satu tujuan pembanguan pemerintah Indonesia dalam agenda pembangunan (nawacita) pada rencana pembangunan jangka menengah nasional (RPJMN) 2015 - 2019, yaitu pelaksanaan program pemerataan dan kewilayahan. Program tersebut dilakukan sebagai upaya untuk mewujudkan pemerataan pembangunan ekonomi dan memperkecil ketimpangan baik ketimpangan antarkelompok pendapatan maupun ketimpangan antarwilayah.

Keberhasilan pembangunan ekonomi di Indonesia tentunya didorong oleh provinsi yang memiliki pembangunan ekonomi yang baik. Berdasarkan data BPS, Jawa Barat sebagai salah satu provinsi yang memiliki kontribusi besar terhadap pembangunan ekonomi di Indonesia dan kontribusinya menempati urutan ketiga tertinggi di Indonesia, di mana kontribusinya sebesar 13,49 persen terhadap PDB nasional. Kondisi ini 
menunjukkan Jawa Barat sebagai penopang perekonomian nasional dan pendorong keberhasilan pembangunan ekonomi di Indonesia. Apabila dilihat dari nilai PDRB perkapita di Jawa Barat, laju pertumbuhan PDRB per kapita di Jawa Barat cenderung fluktuatif dan menurun pada tahun 2019. Hal tersebut juga diikuti dengan melebarnya kesenjangan antara nilai PDRB per kapita tertinggi dan PDRB per kapita tersendah pada kabupaten/kota di Jawa Barat selama 2015 - 2019. Hal tersebut mengindikasikan bahwa kondisi keberhasilan pembangunan ekonomi di Jawa Barat yang relatif maju belum diikuti dengan pemerataan kesejahteraan dan pembangunan antardaerah.

Ketimpangan di Jawa Barat menempati urutan ketiga tertinggi di Indonesia. Selain itu, nilai Indeks Williamson Jawa Barat selalu berkisar pada 0,64 setiap tahunnya. Hal tersebut menunjukkan ketimpangan pembangunan antardaerah di Jawa Barat masuk dalam kategori ketimpangan yang tinggi (Iskandar dan Saragih, 2018). Masalah ketimpangan pembangunan tersebut menjadi perhatian dan fokus pemerintah Jawa Barat dalam program pembangunan setiap tahunnya. Masalah tersebut menjadi target pembangunan pemerintah dalam Rencana Pembangunan Jangka Menengah Daerah (RPJMD) 2015 - 2019. Selama 2015 2019, masalah ketimpangan (indeks gini) Jawa Barat masih lebih tinggi dan belum mencapai target yang ditetapkan pemerintah dalam RPJMD (Bappeda Jawa Barat, 2019). Menurut Saputra (2016), ketimpangan antarkabupaten/kota di Jawa Barat merupakan masalah yang serius dan rata-rata tingkat ketimpangan antarkabupaten/kota tersebut masuk dalam kategori ketimpangan yang tinggi sejak pasca orde baru.

Sejak era industrialisasi, Provinsi Jawa Barat merupakan pusat kawasan industri terbesar di Indonesia. Menurut Kemenprin (2019), Jawa Barat ini memiliki jumlah industri terbanyak di Indonesia, yaitu lebih dari 50 persen dari total jumlah industri di Indonesia. Namun, masalah ketimpangan pembangunan antardaerah di Jawa Barat yang tinggi ini sebagai salah satu dampak dari industrialisasi dan pembangunan industri yang masih terkontrasi di kawasan industri, yaitu di Karawang, Bekasi dan Purwakarta. Untuk wilayah Jawa Barat yang letaknya jauh dari pusat kawasan industri perkembangan industrialiasasinya belum berjalan dengan baik dan struktur perekonomiannya masih dominan pada sektor pertanian, seperti Kabupaten Ciamis, Cianjur, Garut, Majalengka, Pangandaran, Subang, Sukabumi, Tasikmalaya, dan Kota Banjar. Kondisi itu menunjukkan pembangunan industri ini belum merata ke seluruh wilayah, sehingga dapat memperburuk proses pembangunan dan masalah ketimpangan pembangunan antardaerah di Jawa Barat.

Menurut Rahmawati dan Romziatin (2020), konsentrasi industri secara langsung akan meningkatnya ketimpangan pembangunan dan pertumbuhan ekonomi akan cenderung lebih cepat pada daerah yang memiliki konsentrasi industri. Kawasan industri biasanya berkembang pada daerah yang strategis dan terpusat pada beberapa kota besar, serta memiliki produktivitas yang tinggi. Namun, pada daerah non kawasan industri memiliki produktivitas lebih rendah. Oleh karena itu, masalah ketimpangan pembangunan dapat terjadi karena adanya konsentrasi industri. Menurut Kurniawan dan Sugiyanto (2013), terdapat perbedaan konsentrasi kegiatan ekonomi pada sektor industri antardaerah. Pembangunan ekonomi akan berjalan dengan lebih cepat pada daerah dengan tingkat konsentrasi industri yang tinggi, sementara daerah lainnya pembangunan ekonomi akan mengalami penurunan dengan tingkat konsentrasi industri yang rendah. Kondisi tersebut akan mendorong peningkatan ketimpangan pembangunan antardaerah. Selain itu, sektor pertanian berpengaruh meningkatkan ketimpangan pembangunan. Kondisi tersebut diakibatkan karena potensi SDA antarkabupaten/kota untuk pengembangan sektor pertanian berbeda-beda dan sektor pertanian cenderung lebih dominan perananya pada daerah masuk kategori perdesaan. Menurut Todaro dan Smith (2012), aspek pendidikan dan kesehatan tersebut merupakan komponen utama dalam pembangunan ekonomi. Menurut Arsyillah (2019), dengan meningkatnya kualitas dan fasilitas pendidikan dapat meningkatkan akses pelayanan pendidikan, sehingga kualitas SDM semakin baik dan dapat menghasilkan tenaga kerja yang berpendidikan dan memiliki skill yang baik. Adanya SDM berkualitas tersebut tentunya akan mendukung proses pembangunan dan pemerataan pembangunan.

Berdasarkan uraian latar belakang masalah, peneliti tertarik untuk mengalisis pengaruh industri, pertanian, dan sumber daya manusia terhadap ketimpangan pembangunan di Jawa Barat tahun 2015-2019. Variabel yang diduga mempengaruhi masalah ketimpangan pembangunan ekonomi tersebut meliputi faktor industri yang dibatasi pada variabel jumlah industri, jumlah tenaga kerja, dan PDRB sektor Industri, faktor sumber daya alam dengan variabel PDRB sektor pertanian, serta faktor sumber daya manusia yang dibatasi dengan variabel rata-rata lama sekolah (RLS) dan angka harapan hidup (AHH).

\section{METODE}

\section{Landasan Teori}

Teori Hipotesis Neo-Klasik berbentuk kurva U terbalik yang menggambarkan hubungan antara proses pembangunan ekonomi yang berkesinambungan dengan masalah ketimpangan regional. Menurut Hipostesis 
Neo-Klasik, pada awal terjadinya proses pembangunan ekonomi di suatu negara berkembang, ketimpangan pembangunan ekonomi antardaerah cenderung semakin meningkat sampai titik tertentu. Kondisi meningkatnya ketimpangan pada awal pembangunan tersebut sebagai dampak dari proses industrialisasi dan terjadinya urbanisasi di suatu negara. Apabila proses pembangunan terus berlanjut, maka ketimpangan pembangunan antardaerah tersebut akan terus menurun. Kondisi tersebut terjadi ketika kinerja sektor industri yang efektif dan dapat menyerap surplus tenaga keja dari sektor pertanian (Sjafrizal, 2008). Menurut teori Neo-Klasik tersebut, ketimpangan pembangunan antardaerah akan mencapai keseimbangan kembali karena daerah relatif tertinggal dengan sendirinya akan terjadi konvergen dengan daerah maju.

Menurut Simon Kuznent, masalah ketimpangan merupakan konsekuensi dari pembangunan dan pertumbuhan ekonomi dan ketimpangan akan meningkat pada tahap awal pembangunan ekonomi.Simon Kuznet juga menyebutkan faktor utama yang menyebabkan terjadinya, yaitu terpusatnya modal pada kelompok masyarakat berpendapatan tinggi dan adanya pergeseran dari sektor pertanian ke sektor industri yang lebih maju, serta ketersediaan sumber daya alam yang berbeda (Nguyen, et al., 2019)

Menurut Sjafrizal (2008), terdapat lima faktor utama yang menyebabkan terjadinya ketimpangan pembangunan ekonomi antardaerah. Perbedaan kandungan sumber daya alam yang besar antardaerah akan memicu terjadinya ketimpangan pembangunan antardaerah. Menurut Sattar (2018), pembangunan ekonomi daerah yang kaya SDA akan lebih maju dan makmur dibandingkan daerah yang miskin SDA. Perbedaan kondisi demografis antardaerah dapat menyebabkan terjadinya ketimpangan regional. Perkembangan penduduk yang cepat dengan kapasitas yang baik untuk menyerap pengetahuan akan mendorong pembangunan, tetapi perkembangan penduduk yang cepat juga dapat menjadi penghambat pembangunan, seperti tenaga kerja dengan pendidikan rendah, sehingga akan mengakibatkan ketimpangan pembangunan semakin memburuk. Mobilitas barang dan jasa seperti kegiatan perdagangan yang kurang lancar sebagai faktor yang dapat memicu ketimpangan regional. Hal tersebut akan mengakibatkan ketimpangan pembangunan antardaerah akan meningkat karena kelebihan produksi dan tenaga kerja yang tidak dapat terdistribusi secara merata untuk daerah yang membutuhkan. Konsentrasi kegiatan ekonomi yang tinggi di suatu daerah sebagai faktor yang memicu masalah ketimpangan pembangunan. Konsentrasi kegiatan ekonomi ini dapat digambarkan dengan terpusatnya kegiatan sektor industri, sehingga dapat menyebabkan terjadinya ketimpangan pembangunan industri antardaerah. Akibatnya, akan memperburuk masalah ketimpangan pembangunan ekonomi antardaerah (Hasang dan Nur, 2020). Alokasi dana pembangunan daerah dapat digambarkan dengan keadaan invetasi. Daerah yang memiliki investasi yang besar akan mendorong pembangunan menjadi lebih cepat daripada daerah yang memiliki investasi yang relatif kecil.

Dalam penelitian ini digunakan Indeks Jaime Bonet (dengan pendekatan PDRB per kapita relatif) untuk mengukur ketimpangan pembangunan. Indeks tersebut digunakan dalam pengukuran tingkat ketimpangan karena tidak memerlukan data dengan daerah yang lebih kecil daripada daerah penelitian, sebagai indikator yang dapat mengukur ketimpangan dalam daerah dan antardaerah, serta indeks tersebut dapat menggambarkan kondisi kontribusi PDRB perkapita tiap kabupaten/kota terhadap PDRB perkapita provinsi. Formula indeks dalam penelitian yang dilakukan oleh Bonet (2006) yang menggambarkan ketimpangan antardaerah dirumuskan sebagai berikut.

$$
I_{i t}=\left|\frac{P C G D P_{i, t}}{P C G D P_{N A L, t}}-1\right|
$$

Di mana $I_{i t}$ sebagai ketimpangan pembangunan daerah i tahun t, $P C G D P_{i, t}$ yaitu PDRB perkapita daerah i tahun t dan $P C G D P_{N A L, t}$ yaitu PDRB perkapita nasional tahun t. Nilai indeks tersebut berada dalam rentang antara 0 sampai tak terhingga. Jika nilai indeks di suatu daerah tersebut lebih dari satu artinya ketimpangan di daerah yang bersangkutan tinggi.

\section{Regresi Data Panel}

Langkah - langkah dalam melakukan estimasi model regresi data panel, yaitu sebagai berikut.

1. Pembentukan Estimasi Model Regresi Data Panel dan pemilihan model terbaik antara Common Effect Model (CEM), Fixed Effect Model (FEM), dan Random Effect Model (REM). Ada tiga uji untuk pemilihan model terbaik, yaitu Uji Chow untuk memilih model yang terbaik antara CEM dan FEM, Uji Hausman untuk memilih model yang terbaik antara REM dan FEM, dan Uji BP-LM untuk memilih model terbaik antara CEM dan REM (Baltagi, 2005) dan (Greene, 2012).

2. Apabila diperoleh model FEM dilakukan pengujian struktur matriks varians - covarians error dengan Uji Lagrange Multiplier (LM) untuk menguji apakah error bersifat heteroskedastis atau homoskedastik dan Uji Lamda LM $\left(\lambda_{L M}\right)$ untuk menguji apakah ada atau tidak cross sectional correlation pada error. Jika hasil uji diperoleh error homoskedastis dan tidak ada cross sectional correlation metode yang digunakan, yaitu 
Ordinary Least Square (OLS). Jika error bersifat heteroskedastis dan tidak terdapat cross sectional correlation, metode yang tepat digunakan, yaitu Generalized Least Square (GLS) dengan penimbang cross section weight atau Weighted Least Square (WLS). Apabila error bersifat heteroskedastis dan terdapat cross sectional correlation, metode yang digunakan, yaitu FGLS/Seemingly Unrelated Regression (SUR).

3. Melakukan uji asumsi klasik pada model yang terpilih. Untuk estimasi OLS pengujian asumsi klasik yang dilakukan meliputi uji normalitas, homoskedastisitas, nonautokorelasi, dan nonmultikolinieritas. Namun, untuk estimasi dengan metode GLS dan FGLS/SUR, asumsi klasik yang harus terpenuhi adalah normalitas dan nonmultikolinieritas (Gujarati, 2004). Karena GLS dan FGLS/SUR ini dapat mengakomodasi masalah heteroskedastisitas dan autokorelasi (Greene, 2012).

4. Uji Keberartian Model dilakukan dengan uji simultan ( $F$ test), uji parsial ( $t$ test $)$, dan melihat nilai koefisien determinasi dengan adjusted $R$-square (Gujarati, 2004)

5. Melakukan analisis dan interpretasi model. Model yang terbentuk, yaitu FEM dengan metode FGLS/SUR.

$$
\begin{aligned}
& \text { Indeks Bonet }_{i t}=\left(\alpha+\mu_{i}\right)+\beta_{1} \text { Ln_jum_industri }_{i t}+\beta_{2} \text { Ln_TK_Industri }_{i t} \\
& +\beta_{3} \text { Ln_PDRB_Industri }_{i t}+\beta_{4} \text { PDRB_Pertanian } i t+\beta_{5} R L S_{i t}+\beta_{6} A H H_{i t}+v_{i t}
\end{aligned}
$$

Keterangan :

Indeks_Bonet ${ }_{i t}$ : Ketimpangan pembangunan (Indeks Bonet) di kabupaten/kota ke-I pada tahun ke-t

Ln_jum_industri $i_{i t}$ : logaritma natural jumlah industri di kabupaten/kota ke-i pada tahun ke-t

Ln_TK_Industri $i_{i t}$ : logaritma natural jumlah tenaga kerja industri di kabupaten/kota ke-i pada tahun ke-t

Ln_PDRB_Industri $i_{i t}$ : logaritma natural PDRB industri di kabupaten/kota ke-i pada tahun ke-t

$P D R B \_P e r t a n i a n_{i t}$ : nilai PDRB sektor pertanian di kabupaten/kota ke-i pada tahun ke-t

$R L S_{i t}$ : Rata - rata lama sekolah (RLS) di kabupaten/kota ke-i pada tahun ke-t

$A H H_{i t}$ : Angka harapan hidup (AHH) di kabupaten/kota ke-i pada tahun ke-t

$\alpha$ : koefisien intercept

$\beta_{j}$ : koefisien parameter regresi data panel (slope) ke-j $(\mathrm{j}=1,2, \ldots, 6)$

$\mu_{i}:$ efek individu pada kabupaten/kota ke-i

$v_{i t}$ : komponen error dari model pada kabupaten/kota ke-i tahun ke-t

$i$ : induvidu kabupaten/kota di mana $\mathrm{i}=1,2, \ldots, 27$

$t$ : periode waktu $(2015-2019)$

\section{Hipotesis Penelitian}

Berdasarkan identifikasi masalah, Landasan teori, penelitian terkait yang telah dijelaskan sebelumnya, maka muncul beberapa hipotesis penelitian sebagai berikut.

1. Jumlah industri, PDRB sektor industri, dan PDRB sektor pertanian berpengaruh signifikan dan positif terhadap ketimpangan pembangunan di Jawa Barat.

2. Jumlah tenaga kerja industri, Rata-rata lama sekolah (RLS) dan Angka harapan hidup (AHH) berpengaruh signifikan dan negatif terhadap ketimpangan pembangunan di Jawa Barat.

\section{Data dan Sumber Data}

Cakupan wilayah dalam yang digunakan dalam penelitian mengenai ketimpangan pembangunan antarkabupaten/kota ini, yaitu seluruh kabupaten/kota di Provinsi Jawa Barat yang terdiri dari 18 kabupaten dan 9 kota pada periode 2015-2019. Dalam penelitian ini menggunakan data sekunder. Data jumlah industri dan jumlah tenaga kerja industri diperoleh dari Dinas Perindustrian dan Perdagangan Jawa Barat. Data PDRB perkapita ADHK, PDRB ADHK sektor industri, PDRB ADHK sektor pertanian, RLS dan AHH diperoleh dari publikasi BPS Jawa Barat. Data penelitian ini merupakan data panel.

\section{HASIL DAN PEMBAHASAN}

\section{Gambaran Umum Kondisi Perekonomian di Jawa Barat}

Perekonomian di Jawa Barat ditopang oleh sektor industri, sektor perdagangan, dan sektor pertanian. Pada tahun 2015-2019, sektor industri masih mendominasi pada perekonomian di Jawa Barat, dengan kontribusi sektor industri tersebut berkisar antara 41,6-43,07 persen setiap tahunnya. Hal tersebut menunjukkan sektor industri ini sebagai leading sector yang mendorong kinerja sektor-sektor ekonomi lainnya. Berdasarkan data BPS, laju pertumbuhan ekonomi Jawa Barat mengalami fluktuasi pada 2015-2019 dan selalu di atas laju pertumbuhan ekonomi Indonesia. Kondisi itu menunjukkan proses pembangunan ekonomi di Jawa Barat lebih 
cepat dibandingkan dengan pembangunan ekonomi nasional. Hal tersebut terjadi karena pembangunan industri di Indonesia yang masih terkonsentrasi pada kawasan industri di Jawa Barat. Pada tahun 2019 laju pertumbuhan ekonomi menurun yang disebabkan oleh kondisi ekonomi global yang menurun sebesar 2,9 persen dari tahun sebelumnya, serta melemahnya aktivitas perdagangan dan produksi manufaktur dunia. Selain itu, karena pertumbuhan sektor industri menurun dari 6,25 persen menjadi 4,04 persen pada tahun 2019 dan juga kondisi ekspor barang dan jasa yang mengalami kontraksi sebesar -2,89 persen pada 2019 (Pemprov Jawa Barat, 2020). Apabila dilihat pada PDRB perkapita, terdapat perbedaan yang cukup besar pada nilai PDRB perkapita antarkabupaten/kota di Jawa Barat. Untuk setiap tahunnya nilai PDRB perkapita tertinggi terjadi pada Kota Bandung, di mana setiap tahunnya selalu lebih besar dari 60 juta rupiah. Sedangkan, Cianjur selalu memiliki nilai PDRB perkapita terendah dan hanya sekitar 11 juta rupiah hingga 14 juta rupiah. Jangakuan PDRB perkapita antara dua daerah tersebut juga memiliki tren meningkat. Perbedaan tersebut disebabkan karena adanya perbedaan struktur perekonomian antara kedua daerah tersebut. Di Kota Bandung telah mengalami proses industrialisasi dan sektor ekonomi yang menopang perekonomiannya, yaitu sektor industri. Kota Bandung juga sebagai pusat pemerintahan dan kegiatan ekonomi di Jawa Barat. Sedangkan, Kabupaten Cianjur masih ditopang sektor pertanian dan industrialisasinya belum berjalan dengan baik. Hal tersebut menunjukkan distribusi tingkat kesejahteraan dan pembangunan ekonomi di Jawa Barat masih belum merata dan masih terjadi ketimpangan

Kondisi perekonomian di Jawa Barat ini dapat dikaitkan dengan Teori Neo Klasik. Menurut teori tersebut, pada awal terjadinya proses pembangunan ekonomi di suatu daerah, pertumbuhan ekonomi yang cenderung meningkat diiringi dengan ketimpangan pembangunan antardaerah yang cenderung semakin meningkat. Kondisi tersebut sebagai dampak adanya proses industrialisasi (Sjafrizal, 2008). Di mana Jawa Barat ini memiliki laju pertumbuhan ekonomi yang lebih tinggi dari laju pertumbuhan ekonomi nasional, tetapi ketimpangan pembangunan antardaerah di Jawa Barat cukup besar yang disebabkan salah satunya karena industrialisasi dan pembangunan industri masih terkonsentrasi pada kawasan industri.

\section{Ketimpangan Pembangunan di Jawa Barat}

Ketimpangan pembangunan merupakan suatu permasalahan yang serius dan umumnya terjadi dalam proses pembangunan di setiap negara. Menurut Todaro dan Smith (2006), ketimpangan pembangunan dapat menciptakan berbagai masalah ekonomi, sosial dan budaya. Ketimpangan Pembangunan tersebut merupakan masalah yang umum terjadi di semua daerah di Indonesia, termasuk di Jawa Barat.

Dalam penelitian ini, ketimpangan pembangunan antardaerah diukur dengan Indeks Jaime Jaime Bonet, dengan pendekatan PDRB perkapita relatif. Pada tahun 2015-2019, terdapat perbedaan yang cukup besar pada nilai Indeks Bonet antarkabupaten/kota di Jawa Barat. Daerah yang memiliki nilai Indeks Bonet tertinggi, yaitu Kota Bandung dengan rata-rata Indeks Bonet sebesar 1,47. Selain itu, daerah Kabupaten Karawang dan Kabupaten Bekasi juga memiliki rata-rata Indeks Bonet lebih dari satu. Sedangkan, daerah yang memiliki nilai Indeks Bonet paling rendah, yaitu Kota Bogor. Nilai rata-rata Indeks Bonet pada daerah tersebut relatif mendekati nol dan hanya sebesar 0,05. Selain itu, jangkauan nilai Indeks Bonet antara Kota Bandung dan Kota Bogor setiap tahunnya lebih dari satu dan memiliki tren yang meningkat, serta nilai standar deviasi Indeks Bonet tersebut memiliki tren meningkat. Kondisi tersebut menunjukkan bahwa dalam proses pembangunan ekonomi di Jawa Barat ini masih belum merata dan terjadi ketimpangan antarkabupaten/kota yang relatif besar, serta permasalahan ketimpangan pembangunan tersebut semakin serius dan memburuk.

Tabel 1. Ringkasan statistik Indeks Bonet di Jawa Barat tahun 2015 - 2019

\begin{tabular}{lccccc}
\hline Statistik & 2015 & 2016 & 2017 & 2018 & 2019 \\
\hline Max & 1,45 & 1,40 & 1,47 & 1,53 & 1,61 \\
Min & 0,07 & 0,06 & 0,05 & 0,05 & 0,04 \\
Jangkauan & 1,39 & 1,35 & 1,42 & 1,49 & 1,56 \\
Rata-rata & 0,49 & 0,48 & 0,48 & 0,48 & 0,47 \\
Standar deviasi & 0,346 & 0,350 & 0,355 & 0,361 & 0,365 \\
\hline
\end{tabular}

Sumber : BPS Provinsi Jawa Barat (diolah)

\section{Analisis Tipologi Klassen}

Analisis Tipologi Klassen bertujuan untuk mengetahui perkembangan kondisi perekonomian dan pembangunan ekonomi kabupaten/kota di Jawa Barat. Selama 2015-2019 terjadi perubahan pengklasifikasian 
kabupaten/kota dan terdapat lima daerah yang mengalami perubahan klasifikasi. Terjadinya perubahan tersebut menunjukkan adanya perkembangan pada proses pembangunan di kabupaten/kota di Jawa Barat.

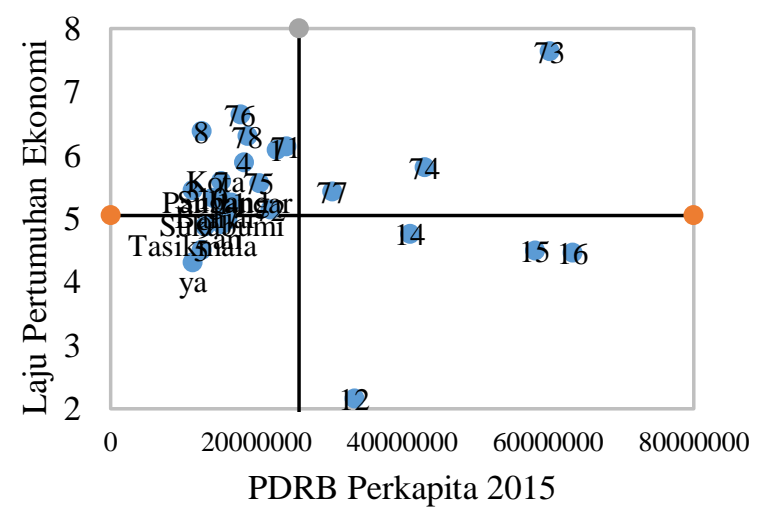

Sumber: BPS Provinsi Jawa Barat (diolah)

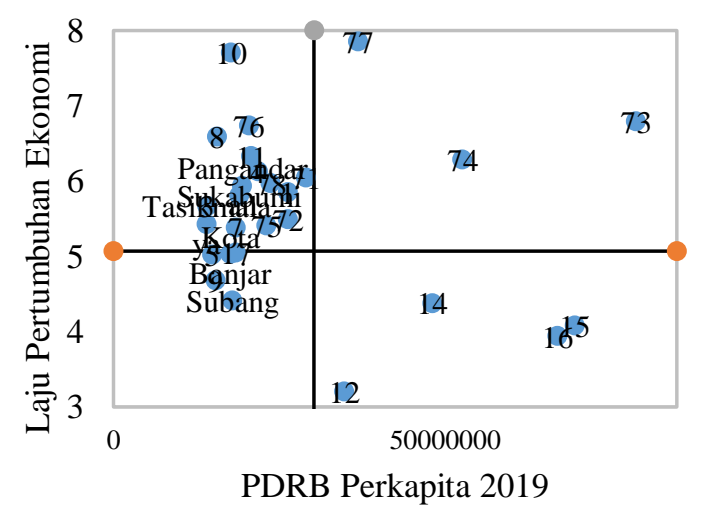

Gambar 1. Klasifikasi kabupaten/kota berdasar Tipologi Klassen tahun 2015 dan 2019

Kabupaten Sukabumi, Tasikmalaya, dan Pangandaran mengalami pergeseran dari daerah yang relatif tertinggal (kuadran IV) pada tahun 2015 menjadi daerah cepat berkembang (kuadran III) pada tahun 2019. Kondisi itu menunjukkan bahwa perkembangan pembangunan ekonomi pada ketiga daerah tersebut membaik dan mengalami peningkatan. Perekonomian di Kabupaten Sukabumi ditopang oleh sektor pertanian dan kinerja sektor pertanian semakin meningkat di mana laju pertumbuhan sektor pertanian yang cukup besar dari $-0,53$ persen tahun 2015 menjadi 4,9 persen tahun 2019 (BPS Kabupaten Sukabumi, 2021). Kondisi tersebut juga didukung dengan terlaksananya program pemerintah dan tercapainya target pemerintah pada program peningkatan produksi pangan, ketahanan pangan, dan dan program sentra produksi pertanian (Dinas Pertanian Kab. Sukabumi, 2019). Di Kabupaten Tasikmalaya, kondisi pembangunan industrinya semakin membaik, di mana distribusi sektor industri dari tahun 2015 - 2019 mengalami peningkatan dari tahun ke tahun, serta laju pertumbuhan sektor industrinya mengalami peningkatan dari 6,35 persen tahun 2016 menjadi 10,31 persen pada tahun 2019 (BPS Kabupaten Tasikmalaya, 2020). Hal itu menunjukkan industrialisasinya sudah mulai berjalan dengan baik, sehingga dapat memicu peningkatan keberhasilan pembangunan. Kabupaten Pangandaran memiliki potensi sumber daya alam melimpah yang dapat dijadikan sebagai daya tarik objek wisata dan dikelola untuk perikanan, agrobisnis, dan agroindustri. Pangandaran juga sebagai daerah tujuan pariwisata, terutama wisata alam dan pantai yang tidak pernah sepi dari kunjungan wisatawan (Bappeda Jabar, 2016). Kondisi pada ketiga daerah tersebut tentunya dapat mendorong pembangunan ekonomi dan laju pertumbuhan ekonominya akan lebih cepat dibandingkan dengan pertumbuhan ekonomi Provinsi Jawa Barat.

Kabupaten Subang dan Kota Banjar mengalami pergeseran dari daerah cepat berkembang (kuadran III) pada 2015 menjadi daerah relatif tertinggal (kuadran IV) pada 2019. Hal tersebut menunjukkan kondisi perekonomian dan proses pembangunan pada kedua daerah tersebut semakin memburuk. Perekonomian kedua daerah tersebut ditopang oleh sektor pertanian. Kabupaten Subang merupakan daerah yang memiliki sumber daya alam yang melimpah, tetapi banyak SDA tersebut belum dimanfaatkan dan dikelola dengan baik dan secara optimal oleh pemerintah. Selain itu, perekonomian di Kabupaten Subang ditopang oleh sektor pertanian dan mayoritas penduduknya bekerja di sektor pertanian. Namun, kinerja sektor pertanian tersebut semakin melemah (BPS Kab. Subang, 2021). Kota Banjar tidak memiliki banyak potensi sumber daya alam dan pemerintah belum dapat secara optimal mengembangkan potensi sumber daya alam tersebut. Selain itu, sebagian besar wilayah di Kota Banjar ini merupakan lahan perkebunan dan hutan lindung yang luas, serta serta mayoritas penduduknya bekerja di sektor pertanian dengan tingkat kesejahteraan yang rendah (Pemkot Banjar, 2021). Dengan adanya hutan lindung tersebut tidak dapat dimanfaatkan atau dikekola sebagai sumber daya yang mendukung proses pembangunan ekonomi di Kota Banjar. Kondisi pada kedua daerah tersebut tentunya dapat mengakibatkan pembangunan ekonominya akan melambat.

\section{Estimasi Model Regresi Data Panel}

Dalam pemilihan model terbaik dengan uji Chow dan uji Hausman. Berdasarkan tabel 2, Uji Chow menunjukkan hasil bahwa tidak terdapat efek individu pada model, sehingga model yang terpilih adalah FEM. Kemudian, dilakukan Uji Hausman, di mana hasilnya menunjukkan terdapat korelasi antara error model dengan variabel bebas, sehingga model yang terpilih adalah FEM. Selanjutnya, dilakukan pengujian struktur 
matriks varians-covarians residual dari FEM dengan uji LM dan uji $\lambda_{L M}$. Uji LM menunjukkan hasil bahwa dari struktur matriks varians-covarians residual bersifat heteroskedastis dan uji $\lambda_{L M}$ menunjukkan hasil ada cross sectional correlation antarresidual. Sehingga, estimasi model yang digunakan, yaitu FEM dengan metode FGLS/Seemingly Unrelated Regression (SUR).

Tabel 2. Ringkasan hasil pemilihan model terbaik, pengujian struktur matriks varians covarians residual, dan pengujian asumsi klasik

\begin{tabular}{|c|c|c|c|c|}
\hline \multicolumn{5}{|c|}{ Pemilihan Model Terbaik } \\
\hline Pengujian & Statistik Hitung & Probability & Keputusan & Kesimpulan \\
\hline Uji Chow & 352,42211 & 0,0000 & Tolak H0 & Terpilih FEM \\
\hline Uji Hausman & 34,322003 & 0,0000 & Tolak H0 & Terpilih FEM \\
\hline \multicolumn{5}{|c|}{ Pengujian Struktur Matriks Varians Covarians Residual } \\
\hline Pengujian & Statistik Hitung & Chi-square Table & Keputusan & Kesimpulan \\
\hline Uji LM & 63,106 & $\chi_{(26)}^{2}=38,85$ & Tolak H0 & Heteroskedastisitas \\
\hline Uji Lamda LM $\left(\lambda_{L M}\right)$ & 943,0696 & $\chi_{(351)}^{2}=395,68$ & Tolak H0 & Ada cross sectional correlation \\
\hline \multicolumn{5}{|c|}{ Pengujian Asumsi Klasik } \\
\hline Pengujian & Statistik Hitung & Probability & Keputusan & Kesimpulan \\
\hline Uji Normalitas & 5,110181 & 0,077685 & Gagal Tolak H0 & Memenuhi \\
\hline \multicolumn{5}{|c|}{ Uji Nonmultikolinearitas (dengan VIF) } \\
\hline LN_INDUSTRI & 3,022461 & - & Kurang dari 10 & Memenuhi \\
\hline LN_TENAGA_KERJA & 2,285197 & - & Kurang dari 10 & Memenuhi \\
\hline LN_PDRB_IND̄USTRI & 6,205870 & - & Kurang dari 10 & Memenuhi \\
\hline PDRB_PERTANIAN & 2,057941 & - & Kurang dari 10 & Memenuhi \\
\hline RLS & 2,773215 & - & Kurang dari 10 & Memenuhi \\
\hline $\mathrm{AHH}$ & 6,534793 & - & Kurang dari 10 & Memenuhi \\
\hline
\end{tabular}

Sumber : Hasil Pengolahan data

Untuk FEM dengan metode FGLS/SUR pelanggaran asumsi heteroskedastis dan autokorelasi sudah terakomodasi (Greene, 2012), dan asumsi klasik yang diuji hanya uji normalitas dan uji nonmultikolinieritas. Hasil uji normalitas dengan uji Jarque Berra menunjukkan error model mengikuti distribusi normal. Uji nonmultikolinieritas dilakukan dengan melihat nilai VIF atau korelasi antarvariabel bebas. Karena nilai VIF lebih kecil dari 10 atau korelasi antarvariabel besar lebih kecil dari 0,8 maka asumsi nonmultikolinieritas terpenuhi (Shrestka, 2020) dan (Gujarati, 2004).

Tabel 3. Ringkasan hasil estimasi FEM dengan metode FGLS/SUR

\begin{tabular}{lcrrr}
\hline \multicolumn{1}{c}{ Variabel Bebas } & Koefisien & Std. Error & t-Statistik & t-Tabel \\
\hline C (intercept) & 1,789747 & 0,638720 & 2,802083 & 1,6599 \\
LN_INDUSTRI & 0,193273 & 0,046339 & 4,170897 & 1,6599 \\
LN_TENAGA_KERJA & $-0,071397$ & 0,013884 & $-5,142400$ & 1,6599 \\
LN_PDRB_INDUSTRI & 0,077978 & 0,021083 & 3,698660 & 1,6599 \\
PDRB_PERTANIAN & 0,022929 & 0,005176 & 4,430101 & 1,6599 \\
RLS & $-0,023071$ & 0,005365 & $-4,300490$ & 1,6599 \\
AHH & $-0,045205$ & 0,010880 & $-4,154853$ & 1,6599 \\
\hline \multicolumn{2}{c}{ Ringkasan } & Statistik & & 3728,104 \\
\hline R-squared & F-statistic & & 0,000000 \\
Adjusted $R$-squared & 0,999146 & Prob(F-statistic) & &
\end{tabular}

Berdasarkan hasil estimasi, persamaan FEM dengan metode FGLS/ SUR dapat dituliskan, yaitu

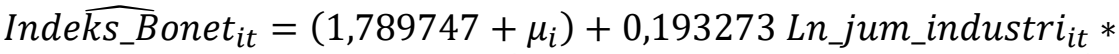

$$
\begin{aligned}
& -0,071397 \text { Ln_TK_Industri }_{i t}{ }^{*}+0,077978 \text { Ln_PDRB_Industri }_{i t}{ }^{*} \\
& +0,022929 \text { PDRB_Pertanian }{ }_{i t}{ }^{*}-0,023071 \text { RLS }_{i t}{ }^{*}-0,045205 \text { AHH }_{i t}{ }^{*} \ldots
\end{aligned}
$$

*) Signifikan pada tingkat signifikansi 5 persen

Nilai $\mathrm{R}^{2}$ adjusted yang diperoleh, yaitu sebesar 0,998878 yang berarti sebesar 99,8878persen dari variasi ketimpangan pembangunan antarkabupaten/kota di Jawa Barat yang diukur dengan Indeks Jaime Bonet dapat dijelaskan oleh variabel jumlah industri, jumlah tenaga kerja industri, PDRB sekto industri, PDRB sektor pertanian, RLS, dan AHH. Sedangkan, sisanya sebesar 0,1122 persen dapat dijelaskan oleh variabel lainnya di luar model. Selanjutnya, dari hasil uji simultan ( F-test) diperoleh hasil bahwa pada tingkat signifikansi 5 
persen keenam variabel bebas di dalam model secara bersama-sama berpengaruh secara signifikan terhadap ketimpangan pembangunan di Jawa Barat. Secara parsial, masing-masing variabel bebas dalam model tersebut berpengaruh secara signifikan terhadap ketimpangan pembangunan di Jawa Barat.

Variabel jumlah industri berpengaruh positif dan signifikan terhadap ketimpangan pembangunan antarkabupaten/kota di Jawa Barat. Nilai koefisien regresinya sebesar 0,193273, yang berarti setiap ada peningkatan 1 persen pertumbuhan jumlah industri akan meningkatkan nilai ketimpangan pembangunan yang diukur dengan indeks bonet sebesar 0,193273 dengan asumsi variabel lainnya tetap (cateris paribus). Hasil yang diperoleh sesuai dengan penelitian dari Rahmawati dan Romziatin (2020) bahwa konsentrasi industri berpengaruh positif dan signifikan terhadap ketimpangan regional. Penelitian tersebut menunjukkan konsentrasi industri secara langsung akan meningkatnya ketimpangan pembangunan daerah dan pertumbuhan ekonomi akan cenderung lebih cepat pada daerah yang memiliki konsentrasi industri. Kawasan industri umumnya berkembang pada daerah yang memiliki akses yang strategis dan industri ini terpusat pada beberapa kota besar saja dan daerah yang berdekatan dengan kawasan industri. Daerah kawasan industri ini tentunya akan memiliki produktivitas yang tinggi. Akan tetapi, untuk daerah non kawasan industri akan memiliki produktivitas lebih rendah. Oleh karena itu, masalah ketimpangan pembangunan dapat terjadi karena konsentrasi industri pada beberapa daerah. Menurut Yusica, Malik, dan Arifin (2018), adanya pengonsentrasian kegiatan ekonomi, seperti aglomerasi industri dapat mengakibatkan terjadinya ketimpangan wilayah. Pengonsentrasian industri di suatu wilayah yang tinggi akan menyebabkan laju pertumbuhan ekonomi lebih cepat, sehingga akan mendorong pembangunan dengan peningkatan lapangan pekerjaan dan pendapatan. Namun, daerah dengan aglomerasi industri yang rendah akan semakin terbelakang.

Variabel PDRB sektor industri berpengaruh positif dan signifikan terhadap ketimpangan pembangunan antarkabupaten/kota di Jawa Barat. Nilai koefisien regresi logaritma natural PDRB sektor industri sebesar 0,077978 yang berarti bahwa setiap ada peningkatan 1 persen pertumbuhan PDRB sektor industri akan meningkatkan nilai ketimpangan pembangunan yang diukur dengan indeks bonet sebesar 0,077978 dengan asumsi variabel lainnya tetap (cateris paribus). Hasil yang diperoleh tersebut sesuai dengan penelitian yang dilakukan oleh Kurniawan dan Sugiarto (2013) bahwa PDRB sektor industri berpengaruh signifikan dan positif terhadap ketimpangan pembangunan. Pada penelitian tersebut menunjukkan adanya perbedaan konsentrasi kegiatan ekonomi pada sektor industri antardaerah yang besar. Di mana pembangunan ekonomi akan berjalan dengan lebih cepat pada daerah dengan tingkat konsentrasi industri yang tinggi, sementara daerah lainnya pembangunan ekonomi akan mengalami penurunan dengan tingkat konsentrasi indsutri yang rendah. Kondisi tersebut akan mendorong peningkatan ketimpangan pembangunan. Menurut Sjafizal (2008), adanya perbedaan konsentrasi kegiatan ekonomi pada sektor industri ini dapat meninbulkan ketimpangan pembangunan antarwilayah. Menurut Chong dan Wu (2014), yang menunjukkan adanya tranformasi struktural dari sektor tradisional menjadi sektor industri dan peningkatan industri di Cina akan meningkatkan nilai tambah dan total output yang berkelanjutan, sehingga dapat meningkatkan pertumbuhan ekonomi. Akan tetapi, dengan adanya industrialiasasi dan peningkatan pembangunan industri juga meningkatkan ketimpangan regional dengan pesat. Hal tersebut diakibatkan karena distribusi industrialiasasi dan peningkatan jumlah industri yang tidak merata, serta distribusi nilai tambah industri tersebut juga tidak terdistribusi secara merata ke seluruh wilayah.

Variabel jumlah tenaga kerja industri berpengaruh negatif dan signifikan terhadap ketimpangan pembangunan antarkabupaten/kota di Provinsi Jawa Barat. Nilai koefisien regresi logaritma natural jumlah tenaga kerja industri sebesar -0,072397, yang berarti bahwa setiap ada peningkatan 1 persen pertumbuhan jumlah tenaga kerja industri akan menurunkan nilai ketimpangan pembangunan yang diukur dengan indeks bonet sebesar 0,072397 dengan asumsi variabel lainnya tetap (cateris paribus). Hasil yang diperoleh tersebut sesuai dengan penelitian yang dilakukan oleh Haryono (2015) bahwa penyerapan tenaga kerja industri secara langsung berpengaruh negatif terhadap ketimpangan di Indonesia. Menurut Dumairy (1996), adanya industrialisasi akan membawa dampak positif untuk mengatasi berbagai permasalahan ekonomi di negara berkembang, seperti mengurangi kemiskinan dan ketimpangan. Berdasarkan teori dari hipotesis Neo-Klasik bahwa ketika sektor industri dapat menyerap surplus tenaga keja dari sektor pertanian dan proses pembangunan terus berlanjut maka ketimpangan pembangunan antardaerah akan terus menurun (Sjafrizal, 2008).

Variabel PDRB sektor pertanian berpengaruh positif dan signifikan terhadap ketimpangan pembangunan antarkabupaten/kota di Jawa Barat. Nilai koefisien regresi variabel PDRB sektor pertanian tersebut sebesar 0,022929, yang berarti bahwa setiap ada peningkatan 1 triliun rupiah nilai PDRB sektor pertanian akan meningkatkan nilai ketimpangan pembangunan yang diukur dengan indeks bonet sebesar 0,022929 dengan asumsi variabel lainnya tetap (cateris paribus). Hasil yang diperoleh tersebut sesuai dengan penelitian dari Kurniawan dan Sugianto (2013) yang menunjukkan sektor pertanian berpengaruh positif dan signifikan terhadap ketimpangan pembangunan antardaerah. Kondisi tersebut diakibatkan karena daya dukung daerah dan potensi sumber daya alam antarkabupaten/kota untuk pengembangan sektor pertanian berbeda-beda dan 
sektor pertanian ini cenderung lebih dominan perananya pada daerah tertentu saja seperti daerah masuk kategori perdesaan atau daerah yang jauh dari pusat perkotaan.

Variabel RLS berpengaruh negatif dan signifikan terhadap ketimpangan pembangunan antarkabupaten/kota di Jawa Barat. Nilai koefisien regresi variabel RLS tersebut sebesar -0,023071, yang berarti bahwa setiap ada peningkatan 1 tahun RLS akan mengurangi nilai ketimpangan pembangunan yang diukur dengan indeks bonet sebesar 0,023071 dengan asumsi variabel lainnya tetap (cateris paribus). Hasil yang diperoleh tersebut sesuai dengan penelitian dari Arsyillah (2019), pendidikan yang diukur dengan RLS memiliki perngaruh negatif dan signifikan terhadap ketimpangan pendapatan. Dengan meningkatnya kualitas pendidikan dan semakin membaiknya fasilitas pendidikan dapat meningkatkan akses pelayanan pendidikan kepada masyarakat, sehingga kualitas sumber daya manusia semakin membaik dan dapat menghasilkan tenaga kerja yang berpendidikan tinggi dan memiliki skill yang baik. Adanya sumber daya manusia yang berkualitas tersebut tentunya akan mendukung proses pembangunan dan pemerataan pembangunan antardaerah. Menurut Abdullah, Doucouliagos, dan Manning (2013), dalam penelitiannya menunjukkan tingkat pendidikan yang baik memiliki pengaruh besar pada masalah ketimpangan, yaitu pada kalangan kelas atas pendapatan akan berkurang dan pada golongan menengah ke bawah pendapatan akan cenderung meningkat. Dengan demikian, faktor pendidikan yang semakin baik dapat mengurangi ketimpangan pendapatan.

Variabel AHH memiliki pengaruh negatif dan signifikan terhadap ketimpangan pembangunan antarkabupaten/kota di Jawa Barat. Nilai koefisien regresi variabel AHH tersebut sebesar $-0,045205$, yang berarti bahwa setiap ada peningkatan 1 tahun AHH akan mengurangi nilai ketimpangan pembangunan yang diukur dengan indeks bonet sebesar 0,045205 dengan asumsi variabel lainnya tetap (cateris paribus). Hasil yang diperoleh sesuai dengan penelitian dari Sabir dan Aziz (2018), AHH berpengaruh negatif dan signifikan terhadap ketimpangan. Hal tersebut berarti peningkatan $\mathrm{AHH}$ atau tingkat kesehatan dapat mengurangi ketimpangan pendapatan. Secara umum, AHH yang semakin tinggi akan meningkatkan produktivitas dan pendapatan tenaga kerja secara keseluruhan, sehingga dapat mengurangi ketimpangan pendapatan antardaerah.

\section{KESIMPULAN}

Berdasarkan hasil dan pembahasan dapat ditarik kesimpulan, yaitu ndustrialisasi dan pembangunan sektor industri di Provinsi Jawa Barat masih belum merata ke seluruh daerah dan masih terkonsentrasi pada kawasan industri. Selain itu, terdapat perbedaan yang besar pada nilai Indeks Bonet dan PDRB perkapita antarkabupaten/kota di Provinsi Jawa Barat. Kondisi tersebut menunjukkan distribusi tingkat kesejahteraan dan pembangunan ekonomi antarkabupaten/kota di Provinsi Jawa Barat masih terjadi ketimpangan. Selama periode 2015-2019 terjadi perubahan klasifikasi kabupaten/kota menurut Tipologi Klassen. Kabupaten Sukabumi, Tasikmalaya, dan Pangandaran terjadi perkembangan baik dari daerah relatif tertinggal pada tahun 2015 menjadi daerah berkembang cepat pada tahun 2019. Kabupaten Subang dan Kota Banjar mengalami pergeseran memburuk dari daerah berkembang cepat pada 2015 menjadi daerah relatif tertinggal pada 2019. Berdasarkan analisis inferensia diperoleh bahwa variabel jumlah industri, PDRB sektor industri, dan PDRB sektor pertanian berpengaruh positif terhadap Indeks Bonet, sedangkan variabel jumlah tenaga kerja industri, rata-rata lama sekolah (RLS), dan angka harapan hidup (AHH) berpengaruh negatif terhadap Indeks Bonet. Kemudian, keenam variabel independen tersebut secara bersama-sama berpengaruh terhadap Indeks Bonet.

\section{DAFTAR PUSTAKA}

Abdullah, A., Doucouliagos, H., \& Manning, E. (2013). Does Education Reduce Income Inequality? A MetaRegression Analysis. Journal of Economic Surveys, 29(2), 1-16. doi:https://doi.org/10.1111/joes. 12056

Arsyillah, R. M. (2019). Analisis Peranan Pendidikan dan Ketenagakerjaan terhadap Ketimpangan Distribusi Pendapatan Indonesia. Universitas Islam Negeri Syarif Hidayatullah. Jakarta.

Baltagi, B. H. (2005). Econometric analysis of panel data (Third Edition). England: John Wilay and Sons. Bappeda Jawa Barat. (2016). Penyusunan Rencana Kebutuhan Investasi Pusat Pertumbuhan Pangandaran Raya 2016. Jawa Barat: Bappeda.

Bappeda Jawa Barat. (2019). Evaluasi terhadap Hasil RPJMD Provinsi Jawa Barat Tahun 2019. Jawa Barat: Pemeritnah Provinsi Jawa Barat.

Bappenas. (2017). Evaluasi Paruh Waktu RPJMN 2015 - 2019 : Kerja Nyata Mewujudkan Indonesia yang Berdaulat, Mandiri, dan Berkepribadian. Jakarta: Kementrian Perencanaan Pembangunan Nasional.

Bonet, J. (2006). Fiscal Decentralization and Regional Indome Disparities : Evidence from the Colombia Experience. Spinger-Verlag, 661 - 676. doi: https://doi.org/10.1007/s00168-066-0060-Z. 
BPS Kabupaten Subang. (2020). Produk Domestik Regional Bruto Kabupaten Subang Menurut Lapangan Usaha 2015 - 2020. Subang: BPS.

BPS Kabupaten Sukabumi. (2021). Distribusi Persentase PDRB Atas Dasar Harga Berlaku Menurut Lapangan Usaha 2010 - 2020. Sukabumi: BPS.

BPS Kabupaten Sukabumi. (2021). Laju Pertumbuhan PDRB Menurut Lapangan Industri 2011 - 2020. Sukabumi: BPS.

BPS Kabupaten Tasikmalaya. (2019). Laju Pertumbuhan PDRB Harga Konstan 2011 - 2019. Tasikmalaya: BPS.

Cheong, T., \& Wu, Y. (2014). The Impact of Structural Transformation and Industrial Upgrading on Region Inequallity in China. China Economic Review, 31, 339-350. doi:https://doi.org/10.1016/j.chieco.2014.09.007

Dinas Pertanian Kabupaten Sukabumi. (2019). Rencana Kerja Dinas Pertanian Tahun 2019. Sukabumi: Pemerintah Kabupaten Sukabumi.

Dumairy. (1996). Perekonomian Indonesia. Jakarta : Erlangga.

Greene, W.H. (2012). Econometric Analysis of Panel Data (Third Edition). New York: Springer.

Gujarati, D.N. (2004). Basic Econometrics (Fourth Edition). New York: Mc Graw Hill/Irwin.

Haryono, T. (2015). Pengaruh Penyerapan Tenaga Kerja Sektor Industri terhadap Ketimpangan Distribusi Pendapatan di Indonesia Tahun 2013. Skripsi Politeknik Statistika STIS. Jakarta.

Hasang, I., dan Nur, M. (2020). Perekonomian Indonesia. Pare-pare: Ahlimedia.

Iskandar, A., dan Saragih, R. (2018). Analisis Kondisi Kesenjangan Ekonomi Daerah : Studi Kasus Kabupaten/Kota di Sulawesi Selatan. Jurnal Info Artha, 2(1), 37 - 52. doi:https://doi.org/10.31092/jia.v2i1.232

Kementrian Perindustrian RI.. (29 April 2019). Jabar Bagian Timur Berpotensi Dikembangkan Kawasan Industri Baru. Retrieved 19 April 2021, from http://kemenprin.go.id/artikel/20609/Jabar-Bagian-TimurBerpotensi-Dikembangkan-Kawasan-Industri-Baru.

Kurniawan, B., \& Sugiyanto, F. (2013). Pengaruh Pertumbuhan Ekonomi,Share Sektor Industri, dan Pertanian serta Tingkat Jumlah Orang yang Bekerja terhadap Ketimpangan Wilayah Antar Kabupaten/Kota di Jawa Tengah Tahun 2002 - 2010. Diponegoro Journal of Economic, 2(1), 1-14. Retrieved from https://ejournal3.undip.ac.id/index.php/jme/article/view/1913

Kusuma, H., Sulistyono, S.W., dan Priyanto, J. (2019). Ekonomi Regional. Malang: UMM Press.

Nguyen, T.C., et al. (2019). What Favtor Affect Income Inequality and Economic Growth in Middle-Income Countries?. Journal of Risk and Financial Management, 12(40), 1-12. doi:https://doi.org/10.3390/jrfm12010040

Pemerintah Kota Banjar. (2010). Laju Pertumbuhan Ekonomi (LPE) Kota Banjar. diakses 21 April 2021, dari https://banjarkota.go.id/lpe.

Pemerintah Provinsi Jawa Barat. (6 Februari 2020). Ekonomi Jabar 2019 Tumbuh 5,07 Persen. Diakses 15 April 2021, dari https://jabarprov.go.id/index.php/news/36389/2020/02/06/Ekonomi-Jabar-2019Tumbuh-507-Persen.

Rahmawati, F., dan Romziatin, F. (2020). Do Industrial Agglomeration and Investment Shrink Regional Inequality?. Jurnal Pendidikan Ekonomi \& $\quad$ Bisnis, $\quad 8(2), \quad 119 \quad-\quad 126$. doi:https://doi.org/10.21009/JPEB.008.2.4.

Sabir, S., \& Nighat, A. (2018). Impact of Health and Education on Income Inequality: Evidence from Selected Developing Countries. Busness \& Economic Review, 10(4), 83-102. doi:https://doi.org/10.22547/BER/10.4.4

Saputra, D. (2016). Analisis Pertumbuhan Ekonomi dan Tingkat Ketimpangan Antar Kabupaten/Kota di Provinsi Jawa Barat. CR Jurnal, 2(1), 1 - 18. doi:https://doi.org/10.34147/crj.v2i1.10

Sattar. (2018). Buku Ajar Perekonomian Indonesia. Yogyakarta: Deepublish.

Shrestka, N. (2020). Detecting Multicollinearity on Regression Analysis. American Journal of Applied Mathematics and Statistic, 8(2), 39 - 42. doi:https://doi.org/10.12691/ajams-8-2-1.

Sjafrizal. (2008). Ekonomi Regional Teori dan Aplikasi. Sumatera Barat: Badouse Media.

Sukrino, S. (2006). Makroekonomi Teori Pengantar (Edisi Ketiga). Jakarta: PT Raja Grafindo Persada.

Todaro, M.P. dan Smith, S.C. (2006). Pembangunan Ekonomi (Edisi Kesembilan). Jakarta: Erlangga.

Todaro, M.P., dan Smith, S.C. (2012). Economic Development (Eleventh Edition). USA : Pearson

Yusica, L.V., Malik, M., dan Arifin, Z. (2018). Analisis Pengaruh Pertumbuhan Ekonomi, Aglomerasi dan

Tingkat Pengangguran terhadap Ketimpangan antarwilayah Kabupaten/kota di Provinsi Kalimantan

Timur. Jurnal Ilmu Ekonomi 2(2), 230 - 240. 